\title{
Production, Characterization and Biocompatibility of Marine Collagen Matrices from an Alternative and Sustainable Source: The Sea Urchin Paracentrotus lividus
}

\author{
Cristiano Di Benedetto ${ }^{1}$, Alice Barbaglio ${ }^{1, *}$, Tiziana Martinello ${ }^{2}$, Valentina Alongi ${ }^{\mathbf{1}}$, \\ Dario Fassini ${ }^{1}$, Emanuele Cullorà ${ }^{1}$, Marco Patruno ${ }^{2}$, Francesco Bonasoro ${ }^{1}$, \\ Mario Adolfo Barbosa ${ }^{3}$, Maria Daniela Candia Carnevali ${ }^{1}$ and Michela Sugni ${ }^{1}$
}

1 Department of Biosciences, University of Milan, Via Celoria 26, 20133 Milan, Italy; E-Mails: cristiano.dibenedetto@unimi.it (C.D.B.); valentina_alongi88@libero.it (V.A.); dario.fassini@gmail.com (D.F.); emanuele.cullora@tiscali.it (E.C.); francesco.bonasoro@unimi.it (F.B.); daniela.candia@unimi.it (M.D.C.C.); michela.sugni@unimi.it (M.S.)

2 Department of Comparative Biomedicine and Food Science, University of Padova, Agripolis Viale dell'Università 16, 35020 Legnaro (PD), Italy; E-Mails: tiziana.martinello@unipd.it (T.M.); marco.pat@unipd.it (M.P.)

3 INEB-Institute of Biomedical Engineering, University of Porto, Rua do Campo Alegre, 823, 4150-180 Porto, Portugal; E-Mail: mbarbosa@ineb.up.pt

* Author to whom correspondence should be addressed; E-Mail: alice.barbaglio@ unimi.it; Tel.: +39-02-5031-4796; Fax: +39-02-5031-4781.

Received: 7 July 2014; in revised form: 26 August 2014 / Accepted: 5 September 2014 / Published: 24 September 2014

Abstract: Collagen has become a key-molecule in cell culture studies and in the tissue
engineering field. Industrially, the principal sources of collagen are calf skin and bones
which, however, could be associated to risks of serious disease transmission. In fact,
collagen derived from alternative and riskless sources is required, and marine organisms
are among the safest and recently exploited ones. Sea urchins possess a circular area of soft
tissue surrounding the mouth, the peristomial membrane (PM), mainly composed by
mammalian-like collagen. The PM of the edible sea urchin Paracentrotus lividus therefore
represents a potential unexploited collagen source, easily obtainable as a food industry waste
product. Our results demonstrate that it is possible to extract native collagen fibrils from
the PM and produce suitable substrates for in vitro system. The obtained matrices appear as
a homogeneous fibrillar network (mean fibril diameter $30-400 \mathrm{~nm}$ and mesh < $2 \mu \mathrm{m}$ ) and 
display remarkable mechanical properties in term of stiffness (146 $\pm 48 \mathrm{MPa})$ and viscosity $(60.98 \pm 52.07 \mathrm{GPa} \cdot \mathrm{s})$. In vitro tests with horse pbMSC show a good biocompatibility in terms of overall cell growth. The obtained results indicate that the sea urchin P. lividus can be a valuable low-cost collagen source for mechanically resistant biomedical devices.

Keywords: sea urchin collagen; native fibril; collagen matrix; biocompatibility; tissue regeneration; mesenchimal stromal cells

\section{Introduction}

Collagen is the main structural component of animal tissues and shows peculiar mechanical properties conferring strength and elasticity to the tissue itself. The use of collagen as a biomaterial for scaffold development is a topic of great interest, particularly in the tissue engineering field $[1,2]$.

The most used commercial sources of collagen are calf skin and bones, which, however, could carry the risk of serious disease transmission (i.e., bovine spongiform encephalopathy) [3]. This induced researchers to investigate alternative collagen sources, the most interesting and promising ones coming from marine organisms. Scaffolds made of soluble jellyfish or squid collagen exhibited lower immunogenicity and higher cell viability than other naturally derived biomaterials, including bovine collagen, gelatin, hyaluronic acid and glucan $[3,4]$.

Furthermore, good cell viability and osteo-inductive potential was displayed by scaffolds derived from marine sponges [5]. This latter in vitro feature is in agreement with the fact that collagen plays a fundamental role as universal template for in vivo skeletogenesis processes in marine invertebrates [6,7].

Collagen derived from fish, as well as from cuttlefish outer skin waste material, is also under evaluation as a promising alternative $[8,9]$.

Among marine organisms sea urchins are very common coastal inhabitants. They possess a soft membranous area surrounding their mouth: the peristomial membrane (PM) (Figure 1a,b).

The PM mainly consists of a thick ossicle-reinforced dermal layer externally covered by an epidermis and internally by a coelomic epithelium. The collagenous meshwork is the most significant component in terms of both structure and mechanical properties [10,11].

The PM collagen is similar to the mammalian type-I in terms of chain composition, immunoreactivity and ultrastructure (D-period) [12-14] and therefore may represent a suitable alternative source of collagen to be used for biomedical applications. In this research we specifically focused on the common sea urchin Paracentrotus lividus, the main Mediterranean and North-Atlantic edible species [15]. Its gonads are collected for food purpose and the rest of the body, including the PM, is discharged: therefore this waste-material can be potentially exploited for an "eco-friendly" and low-cost collagen extraction. Additionally, sea urchins are harvested in several countries (Japan, USA, France), thus potentially allowing an industrial and constant supply of rough collagenous material to be used by biotech companies. 
Figure 1. The peristomial membrane of P. lividus. (a) Oral side of P. lividus. Around the mouth $(\mathrm{m})$, the peristomial membrane $(\mathrm{pm})$ is well detectable; (b) Schematic anatomy of the peristomial membrane. Dermis (de), ossicles (sp), epidermis (ep), coelomic epithelium (ce). Reproduced with permission from [11]; published by Ital. J. Zool., Journals Taylor \& Francis Group, 1995.
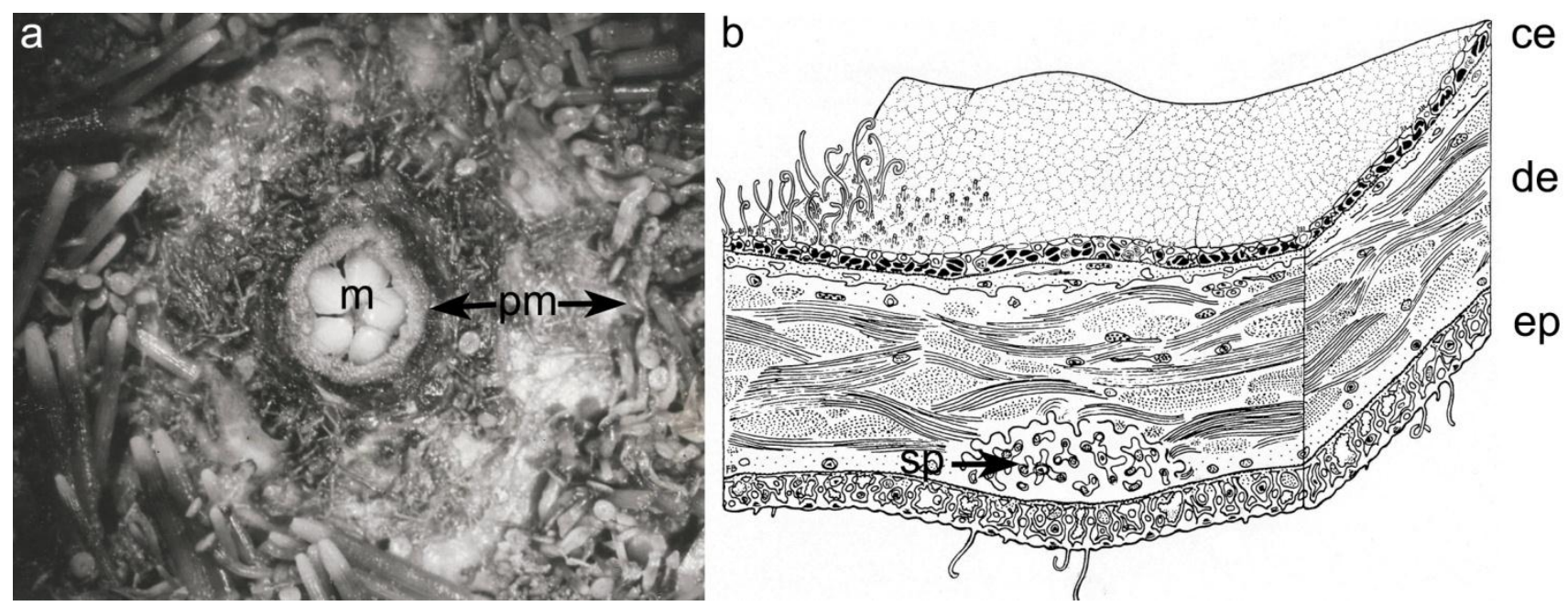

Differently from most commercial mammalian collagens, sea urchin collagen cannot be extracted by traditional methods of acid solubilization, which normally make it in a hydrolyzed jelly form. On the contrary PM collagen is easily extracted in its insoluble fibrillar form, i.e., the native form. This characteristic provides the considerable advantage of producing scaffolds/substrates more closely mimicking the natural extracellular matrix (ECM) and potentially displaying higher mechanical performances. In tissue engineering it is now well known that mechanical properties and scaffold geometry/ultrastructure play a crucial role in cell differentiation and specification [16,17]. By specifically implementing and adjusting previous protocols $[18,19]$, we were able to isolate undamaged native collagen fibrils from the sea urchin P. lividus [20] in a sufficient amount and purity to produce fibrillar scaffolds.

In tissue engineering the assembling of collagen fibrillar matrices usually includes fibrillization steps on partly defibrillated or hydrolized collagen [21,22]. This method causes the production of fibrils which are only partially similar to the native ones in terms of structure and mechanical properties [22]. Among the authors who worked with native collagen fibrils from both vertebrates [23-32] and invertebrates [18,33-37], only a few, i.e., [30,32] — and exclusively in vertebrates-produced substrates for cell cultures using this type of collagen (in literature often regarded as "insoluble collagen").

Irrespective of its form (hydrolized or fibrillar), collagen for scaffolding needs appropriate cross-linking procedures for stabilizing the matrix and, if needed, for reducing enzymatic degradation phenomena when surgically implanted in vivo. Since a few years ago, glutaraldehyde was one of the most used substances for collagen crosslinking, but it was recently substituted by other compounds due to its potential cell toxicity [38,39]. Among alternative biocompatible cross-linkers, EDC-NHS [1-Ethyl-3-(3-dimethylaminopropyl)-carbodiimide (EDC)/Nhydroxysuccinimide (NHS)] is well known and widely used for its several advantages and for in vitro system applications [3,40-43]. 
The present work is addressed to evaluate sea urchin collagen as a potential low-cost alternative for the production of scaffolds for biomedical applications. This was achieved following different steps and approaches, including the development of a specific protocol for fibrillar collagen extraction and matrix preparation as well as a deep evaluation of the produced matrices in terms of ultrastructure, mechanical properties (stiffness and viscosity) and in vitro biocompatibility.

\section{Results and Discussion}

\subsection{Collagen Extraction}

As previously underlined, most of the common and industrial methods for collagen extraction are based on an acid-solubilization and partial hydrolysis of the collagen triple helix [22], which consequently involves the partial or total loss of structural fibril organization. The method we developed here leads to the extraction of intact collagen fibrils from P. lividus PM.

Besides the basic collagen matrix, the PM contains other different components (cellular elements, ossicles; Figure 1b), which represent a serious obstacle in obtaining a clean fibril suspension (Figure 2a).

In order to properly remove both cell debris, skeletal parts and pigments, the minced native tissue was sequentially treated with two different specifically developed solutions: a hypotonic solution and a SDS-based decellularizing solution [20,44]. The former induced cell lysis whereas the latter removed cell debris and most of the non-collagenous extracellular material acting as a detergent (Figure 2b). Only the most strictly fibril-associated glycosamynoglycans (GAGs) remained, periodically organized along the fibril surface according to the standard D-patterning (Figure 2c,d). The presence of these GAGs is important to preserve fibril integrity [45], can increase matrix hydrophylicity (GAGs are polianionic molecules) and allows the production of a more biomimetic collagen matrix. Indeed, the ECM naturally contains GAGs and proteoglycans (GAG-protein association), which are important for several functions including tissue hydration, structural organization and cell adhesion. In tissue engineering, GAGs are often secondarily added to improve scaffold structural, mechanical and physiological performances [46].

Careful PBS washing of the minced tissue before the final disaggregation step (in $\beta$-mercapto-ethanol solution) resulted a crucial passage: an incomplete removal of SDS strongly reduced the yield of following fibril extraction. On the other hand SDS treatment was clearly necessary for obtaining a clean collagen suspension suitable for scaffold production.

After 3-4 days in the disaggregating solution a suspension of fibrils could be observed (Figure 2b).

Undissociated collagen fibers were then removed by a filtration step, although increasing the purity of the extracted fibrils, often implied a partial loss of material and might be problematic due to filter occlusion. The employment of a gradual two-step filtration $(200 \mu \mathrm{m}$ mesh filtering followed by a $100 \mu \mathrm{m}$ mesh passage) represented the best compromise between the need of obtaining a clean collagen suspension and the effective yield of collagen extraction from the PM. 
Figure 2. Collagen fibrils. (a) Collagen aqueous fibrillar suspension obtained by a protocol in which the hypotonic and decellularizating solutions were omitted. The brown color is mainly due to the presence of cell debris and pigments; (b) Clean aqueous collagen fibrillar suspension obtained by the complete protocol; (c) Transmission Electron Microscope (TEM). Cuprolinic Blue staining on isolated collagen fibrils. After collagen extraction, fibril-associated glycosaminoglycans (GAGs) could be detected periodically organized along the fibril surface (arrows); (d) TEM, negative staining on isolated collagen fibrils. The collagen fibril D period is clearly visible.
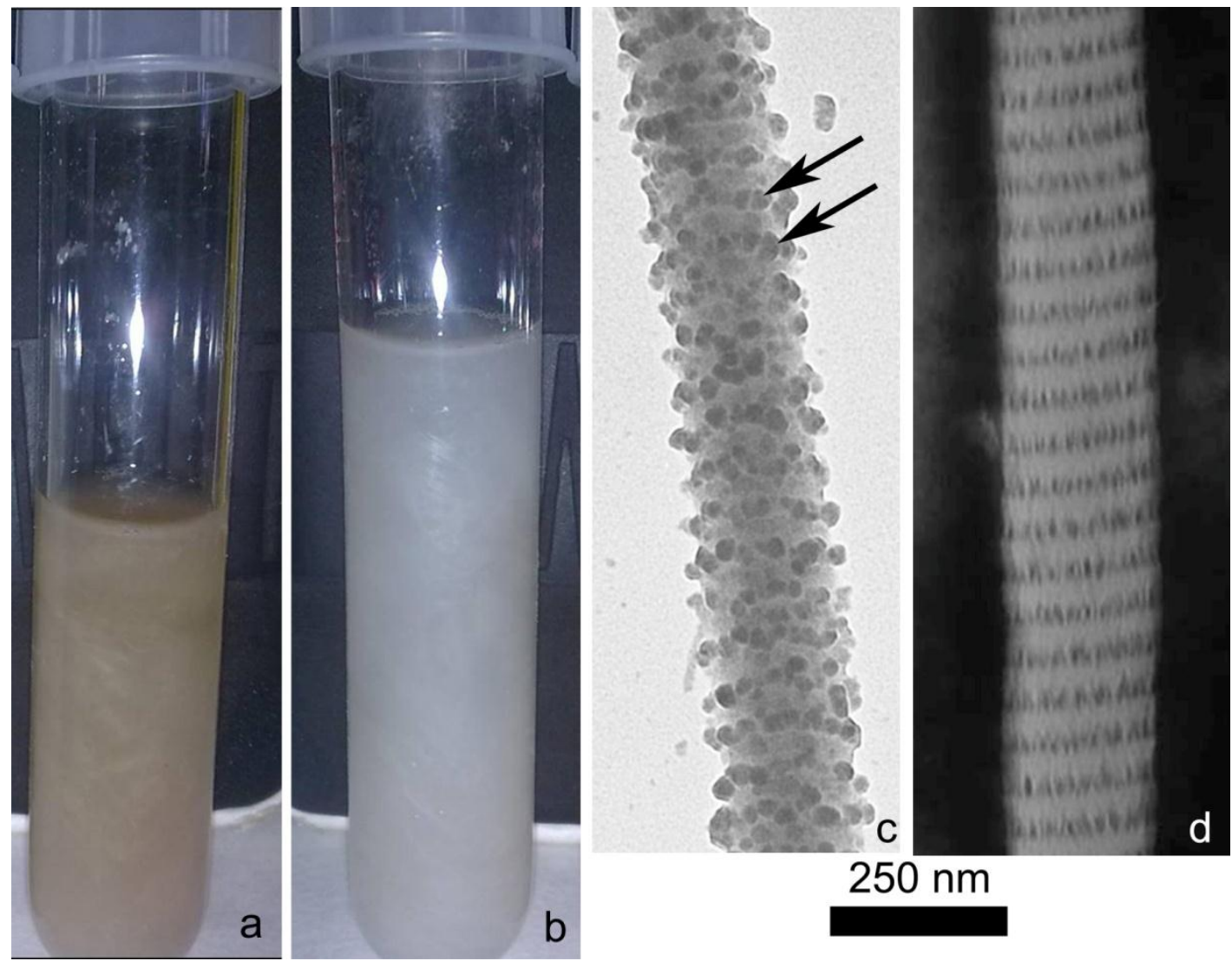

Removal of the $\beta$-mercapto-ethanol (that might be toxic for cells if present in high concentrations) was obtained dialyzing the collagen suspension against EDTA $(3 \mathrm{~h})$ and, subsequently, against distilled water (overnight), which represented the final stocking medium. SDS-page analyses (Figure 3) showed that the main proteins contained in the obtained suspension correspond to the $\alpha_{1}(140 \mathrm{kDa})$ and $\alpha_{2}$ $(120 \mathrm{kDa})$ sea urchin type I-like collagen chains previously described in the literature [13,47]. As expected for collagen SDS-page, some of these chains do not completely dissociate under denaturating condition thus producing the characteristic $\beta$-sheet bands at $260 \mathrm{kDa}\left(\alpha_{1}+\alpha_{2}\right)$ and $280 \mathrm{kDa}\left(\alpha_{1}+\alpha_{1}\right)$. Overall these biochemical data confirm the main collagenous nature of the fibrillar suspension. Further more detailed analyses will help to clarify the nature of the other observed bands (e.g., other collagen types or collagen associated proteoglycans). 
Figure 3. SDS-PAGE gel of the obtained sea urchin collagen suspension. $* *=\alpha_{1}$ collagen chain; $*=\alpha_{2}$ collagen chain. Lane $1=$ marker. Lane $2=$ collagen suspension.

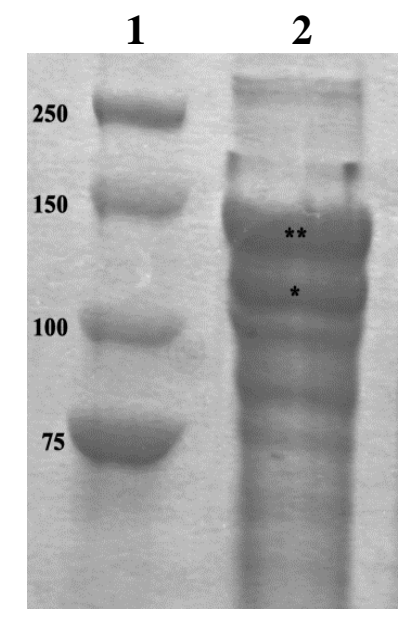

The protocol here described represents the most effective technique to obtain a pure and highly concentrated fibril suspension. Collagen yield from the PM was calculated: in optimal conditions and taking into account 7 different collagen stocks produced in different periods of the year, the average yield is $7 \%$ (dry weight collagen fibrils/dry weight PM). This is a much higher value if compared to the yield previously obtained in mammals with a similar protocol [24]. The classical acid-based extraction procedures might provide higher yields, but usually implies damages of fibril structural integrity [31].

The obtained aqueous collagen suspension (Figure $2 \mathrm{~b}$ ) can be directly stored at $-20{ }^{\circ} \mathrm{C}$ for at least 3 months without significant problems in re-suspension as on the contrary occurred with solid collagen stocks (dried at $37^{\circ} \mathrm{C}$ in silicone molds).

\subsection{Collagen Matrix Production}

The collagen suspension was centrifuged, resuspended in Triton-X-100 $0.01 \%$, plated on cell culture dishes and left to dry. This step was necessary to minimize surface tension phenomena and thus produce a quite homogeneous matrix thickness on the plastic dish (Figure 4a,b).

Omission of T-X-100 caused a collagen network deposition confined to the dish borders.

Collagen matrices needed to be cross-linked in order to have suitable mechanical properties for in vitro studies or biomechanical manipulations. The collagen matrix was therefore exposed to EDC/NHS mix solution, which acts as a fibril crosslinking agent. After $4 \mathrm{~h}$ of exposure, the collagen film resulted tightly adhering to the plastic surface. No significant detachment phenomena were observed, and the inter-fibrillar crosslink apparently displayed a remarkable resistance, even after numerous washings with different media (see Experimental section).

Among the chemical methods for collagen crosslinking, EDC/NHS appeared to be the best option both for providing mechanical resistance to the matrices and for its biocompatibility, already tested by different authors [3,40-43]. 
Figure 4. Sea urchin collagen matrix (SCM). (a) Light microscopy (LM). After the treatment with Tx-100, collagen fibrils resulted homogeneously distributed on the plastic surface; (b) Scanning Electron Microscope (SEM). No cell debris, skeletal parts or undissociated collagen fibers are visible among fibrils; (c) LM. The average thickness of SCM is 5-7 $\mu \mathrm{m}$. The thickness could slightly vary depending on the different areas of the matrix; (d) SEM. Different fibrils with different diameters are present in the SCM; (e) SEM. The average porosity of the matrix (mesh of the fibrillar interlace) is around $1-2 \mu \mathrm{m}^{2}$. Below is an example of interlace area measurement. Pa1 $=753 \mathrm{~nm}$ (major length); $\mathrm{Pa} 2=253 \mathrm{~nm}$ (minor length). The area resulted less than $0.2 \mu \mathrm{m}^{2}$; (f) SEM. Collagen D period is well detectable on collagen fibrils.
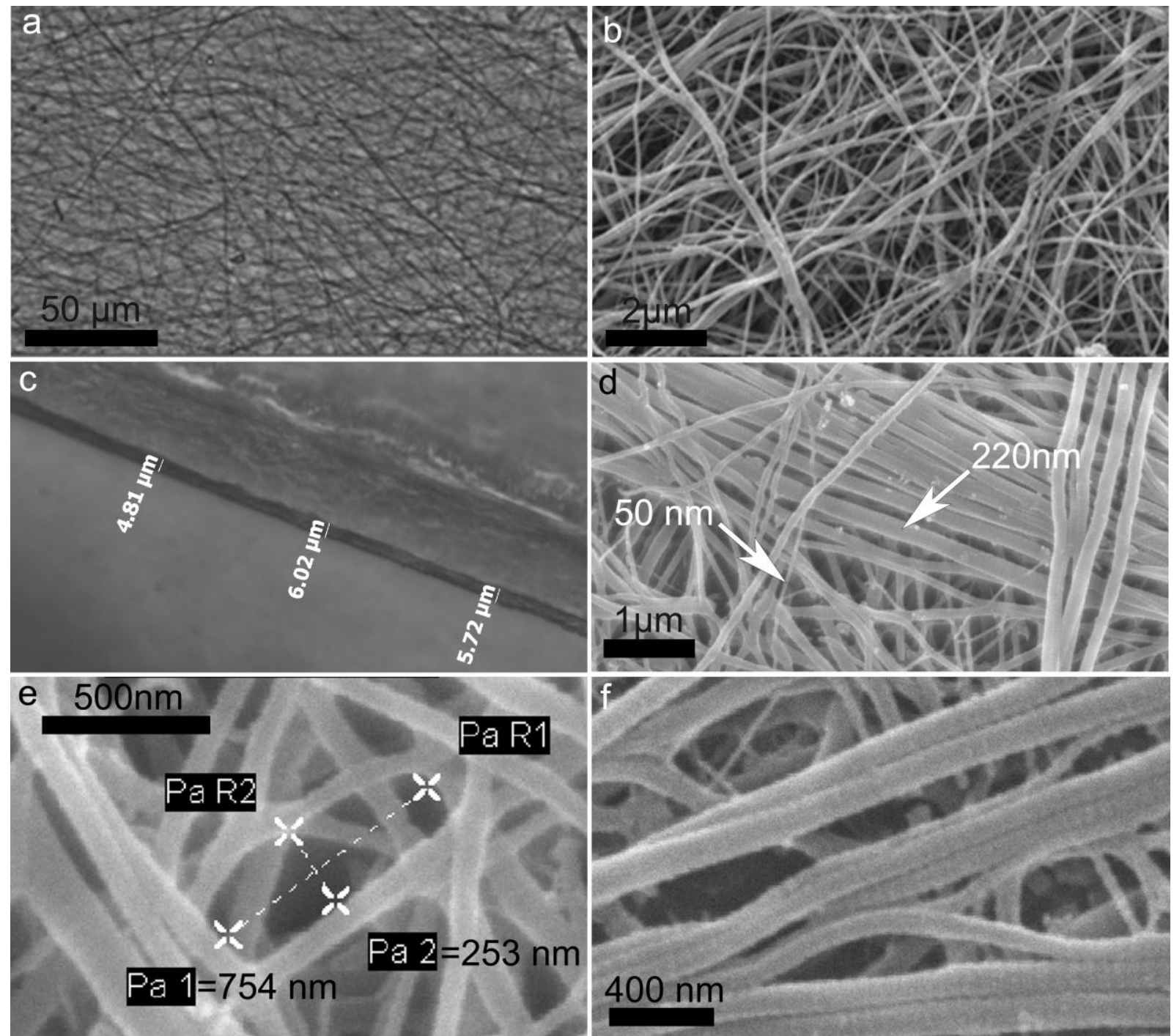

\subsection{Characterization of Collagen Matrices}

The sea urchin collagen matrices (hereafter referred as SCMs) were observed by SEM to investigate the ultrastructural characteristics of the fibrils as well as their reciprocal interactions and organization. After preliminary tests to find optimal concentrations, SCMs were prepared in a 24 multi-wells using $300 \mu \mathrm{L}$ of collagen suspension at the concentrations of $2 \mathrm{mg} / \mathrm{mL}$. Values below these limits barely 
produced a complete and homogeneous covering of the surface. The so produced SCM had an average thickness of 5-7 $\mu \mathrm{m}$. (Figure 4c).

SEM and light microscopy observations showed a randomly distributed fibril pattern and confirmed the absence of undesired aggregates (cell debris, skeletal parts or undissociated collagen fibers) between the fibrils (Figure 4a,b). Fibril diameter ranged between $25 \mathrm{~nm}$ and $300 \mathrm{~nm}$ (Figure 4d) which corresponds to what has been reported for mammalian fibrils [48] as well as for the PM [10]. Sea urchin collagen denaturation temperature is $27^{\circ} \mathrm{C}$ in Strongylocentrotus purpuratus [49]. Nevertheless, despite the step at $37^{\circ} \mathrm{C}$, the experimental protocol did not influence the final chance to get a matrix where fibrils maintained their integrity and could be efficiently cross-linked.

The SCM "porosity" (mesh of the fibrillar interlace) was maximum 1-2 $\mu \mathrm{m}^{2}$ on the superficial layer (Figure 4e). These values are referred to the dry matrix, observed under SEM high vacuum conditions, and might be slightly higher in wet conditions (as in cell culture studies or in vivo applications). Empirical and preliminary calculation of the swelling ratio indicated that the wet matrix increased its thickness of about 30\%. Even considering this swelling variation, the density of collagen matrix is such that mammalian cells could hardly penetrate it and only surface adhesion can be expected.

The D period of collagen fibrils could be clearly observed both after collagen extraction (Figure $2 \mathrm{~d}$ ) and matrix preparation (Figure 4f). This further indicates that the overall protocol did not affect fibril structural integrity.

\subsection{Biomechanics}

Creep (isotonic) and force-extension (isometric) tests were specifically designed and employed to mechanically test the SCM.

\subsubsection{Creep Tests}

Maximum stress and viscosity of the SCM were calculated in hydrated conditions (Leibovitz cell culture medium) in order to more closely mimic physiological in vitro or in vivo applications. The initial load (39.57 g) was gradually increased until complete rupture of the collagen scaffold. The breaking load was $17 \pm 2.8 \mathrm{MPa}$ (mean $\pm \mathrm{SD}$ ) with minimum and maximum registered values of 13.97 $\mathrm{MPa}$ and 24.56 MPa, respectively.

Collagenous samples, when subjected to a tensile stress, underwent a typical elongation pattern that consisted of three main phases: a primary phase immediately after load application, in which the collagen fibrils of the sample rearranged rapidly, resulting in a substantial sample elongation; a secondary phase in which the extension rate tended to stabilize and in which the viscosity was calculated; a final phase, where the sample was no longer able to support the load and broke. Our results showed that the SCM had generally a very fast primary phase $(<2$ s) suggesting that the orientation of the collagen fibrils was very rapid soon after the stress was applied. This implies that EDC/NHS crosslinking does not block fibrils in a strictly fixed disposition, thus allowing a certain level of structural matrix reorganization. The tests showed a relatively high variability in the mechanical tensile resistance. 7/36 samples underwent rupture few seconds after starting the test (tensile stress at start was 14-17 MPa), whereas 15/36 samples ruptured within 3 min from the application of the tensile stress. This implies that most of the samples were not able to resist for a long 
period to a single applied stress of 14-17 MPa. On the other hand, 14/36 samples needed multiple and progressive loads additions before rupture. In this latter case we could calculate the viscosity of the sample in a range between $14 \mathrm{MPa}$ and $24 \mathrm{MPa}$. Overall, the mean final viscosity of all the tested SCM was $60.98 \pm 52.07 \mathrm{GPa} \cdot \mathrm{s}$. This value is much higher than that measured in most fresh tissues of sea urchins and other echinoderms (crinoids, sea cucumbers, etc.) as well as in mammalian tissues (human tendons) (Table 1).

Table 1. Viscosity of different collagenous tissues. Values are reported as mean $\pm \mathrm{SD}$ or range.

\begin{tabular}{ccc}
\hline Structure & Viscosity (MPa·s) & References \\
\hline Sea urchin compass depressor ligament (P. lividus) & $560.6 \pm 364.7$ & {$[50]$} \\
Sea urchin spine joint ligament (Diadema setosum) & $20-5860$ & {$[51]$} \\
Sea cucumber dermis (Stichopus japonicus) & $3.0 \pm 5.6$ & {$[52]$} \\
Sea cucumber dermis (Holothuria leucospita) & 11 & {$[52]$} \\
Sea cucumber dermis (Actinopyga echinites) & 100 & {$[52]$} \\
Sea cucumber dermis (Thyone inermis) & 5100 & {$[53]$} \\
Brittle star intervertebral ligament (Ophiocomina nigra) & $2260 \pm 1940$ & {$[54]$} \\
Feather star stalk (Cenocrinus asterius) & 16,700 & {$[55]$} \\
Human patellar tendon & $438.13 \pm 232.2$ & {$[56]$} \\
\hline
\end{tabular}

Only the cirrus apparatus of the crinoid Cenocrinus asterius has a higher viscosity than that recorded in our samples (Table 1). Noteworthy, soluble porcine collagen films crosslinked with glutaraldehyde displayed a maximum viscosity of $230.53 \mathrm{MPa} \cdot \mathrm{s}$ [57]. This result underlines the relevant mechanical resistance to tensile stress exerted by the SCM, which reflects the presence of strong internal interfibrillar bonds. Most of these bonds were likely due to an effective EDC/NHS collagen crosslinking, possibly helped by the GAG-decorated fibrillar structure of the employed collagen.

\subsubsection{Force-Extension Tests}

SCM were also evaluated in terms of stiffness (Young's modulus or elastic modulus). This parameter indicates the capability of a material to resist when subjected to forced elongations (or from another point of view predicts how it reacts to a tensile stress) and it depends on the structural characteristics of the material itself. Stiffness is one of the most important parameters for material engineering applications. Higher stiffness implies less elastic deformation magnitude in response to mechanical stresses and higher energy storage without plastic deformation.

In our tests the mean calculated stiffness was $146 \pm 48 \mathrm{MPa}$ (range: 91-206 MPa) and the mean tensile strength (tension before rupture) was $44.58 \pm 9.56 \mathrm{MPa}$ (range 32.85-66.19 MPa) whereas mean tensile strain (relative elongation before rupture) was $32.3 \% \pm 5.8 \%$.

The stiffness of native collagenous tissues/substrates reported in literature is highly variable (Table 2), covering a range from $\mathrm{kPa}$ (soluble collagen substrates) to GPa (bones).

Our results, summarized in Table 3, indicate that, even in wet (physiological) conditions, the SCM is a highly resistant material, particularly to uniaxial tensions, with stiffness values in the range of mammalian Achille's tendons or skin (Table 2). Furthermore, this is an extremely high value if compared to most of the commonly used cell culture collagen substrates, which usually are in an 
acid-solubilized jelly form. As previously underlined, acid-treatment can cause a partially irreversible denaturation of the collagen molecules, which therefore might reduce its natural and intrinsic mechanical resistance.

Table 2. Stiffness values of different collagenous structures. Values are reported as mean \pm SD or range.

\begin{tabular}{ccc}
\hline Structure & $\begin{array}{c}\text { Stiffness (Elastic or } \\
\text { Young's Modulus) }\end{array}$ & References \\
\hline Sea urchin compass depressor ligament (P. lividus) & $16.65 \pm 8.93(\mathrm{Mpa})$ & {$[50]$} \\
Sea urchin spine catch apparatus (Anthocidaris crassispina) & $90 \pm 0.87(\mathrm{Mpa})$ & {$[58]$} \\
Sea cucumber dermis (Actinopyga mauritiana) & $1(\mathrm{Mpa})$ & {$[59]$} \\
Sea cucumber single native collagen fibril (C. frondosa) & $1-2(\mathrm{Gpa})$ & {$[36]$} \\
Bovine single collagen fibril & $0.2-0.8(\mathrm{Gpa})$ & {$[60]$} \\
Rat Achille's tendon (Rattus norvegicus) & $310(\mathrm{Mpa})$ & {$[61]$} \\
Pig liver & $6.9-34.7(\mathrm{kPa})$ & {$[62]$} \\
Human skin & $98.97 \pm 97(\mathrm{Mpa})$ & {$[63]$} \\
Human cornea & $0.3-7(\mathrm{Mpa})$ & {$[64]$} \\
Human articular cartilage (hip joints) & $1.816 \pm 0.868(\mathrm{Mpa})$ & {$[65]$} \\
Human cortical bone (femoral diaphysis) & $17.9(\mathrm{Gpa})$ & {$[65]$} \\
Bovine Trabecular bone material & $0.76 \pm 0.39(\mathrm{Gpa})$ & {$[66]$} \\
EDC crosslinked bovine collagen & $31 \pm 4.4(\mathrm{Mpa})$ & {$[67]$} \\
Soluble rat tail collagen (1-3 mg/mL) & $1-28(\mathrm{kPa})$ & {$[68]$} \\
PCL/collagen scaffold crosslinked with glutaraldheyde & $11(\mathrm{Mpa})$ & {$[69]$} \\
\hline
\end{tabular}

Table 3. SCM mechanical properties. Values are reported as mean \pm SD; $n$ : number of samples.

\begin{tabular}{|c|c|c|}
\hline \multicolumn{3}{|c|}{ Sea Urchin (P. lividus) Collagen Matrices (SCM) } \\
\hline Mechanical Properties & Mean \pm SD & $n$ \\
\hline $\begin{array}{c}\text { Viscosity } \\
\text { Breaking load }\end{array}$ & $\begin{array}{c}60.98 \pm 52.07 \mathrm{GPa} \cdot \mathrm{s} \\
17 \pm 2.8 \mathrm{MPa}\end{array}$ & 36 \\
\hline Stiffness (Elastic or Young's modulus) & $146 \pm 48 \mathrm{MPa}$ & \\
\hline Tensile strength & $44.58 \pm 9.56 \mathrm{MPa}$ & 19 \\
\hline Tensile strain & $32.3 \% \pm 5.8 \%$ & \\
\hline
\end{tabular}

Grover et al. [67] showed that substrates prepared from a fibrous bovine collagen suspension, crosslinked by EDC-NHS, displayed a stiffness of $31 \pm 4.4 \mathrm{MPa}$ (wet conditions), a nearly 5 folds lower value than that we obtained with SCM which was similarly crosslinked.

A high elasticity of the SCM was observed by comparing the average thickness before and after the mechanical tests and by analyzing the fracture area (SEM and confocal observations). Indeed, the average thickness of the samples did not significantly vary after the mechanical testing $(11.16 \pm 3.18 \mu \mathrm{m}$ before; $10.91 \pm 3.18 \mu \mathrm{m}$ after) and its value was constant along the entire length of the samples. Additionally, the fracture surface appeared quite sharp confirming the absence of a plastic deformation. 


\subsection{In Vitro Biocompatibility}

Preliminary biocompatibility tests were performed to assess mammalian cell behavior when in contact with the SCM; indeed, since these substrates might be used for tissue engineering and regenerative medicine purposes, a first fundamental requirement is the lack of cytotoxicity. Having in mind these potential applications we decided to focus on primary stem cell cultures rather than well established cell lines: mesenchymal stem cells (MSCs) isolated from peripheral blood of horses were therefore grown on SCM to check its suitability as cell substrate. Overall, both cell counting and Cell proliferation Assay (XTT) indicated that the SCM are not toxic for MSCs: despite the lower absolute values than on plastic, cells adhered, survived and in the medium-long time (7-21 days) they also increased in number (Figures 5 and 6), thus suggesting an active proliferation.

Figure 5. Cell counting of mesenchymal stromal cells (MSCs) seeded on SCM and on plastic at $24 \mathrm{~h}, 4$ and 7 days. Each histogram represents the mean \pm SD of four experiments; * $p<0.05$ plastic versus SCM.

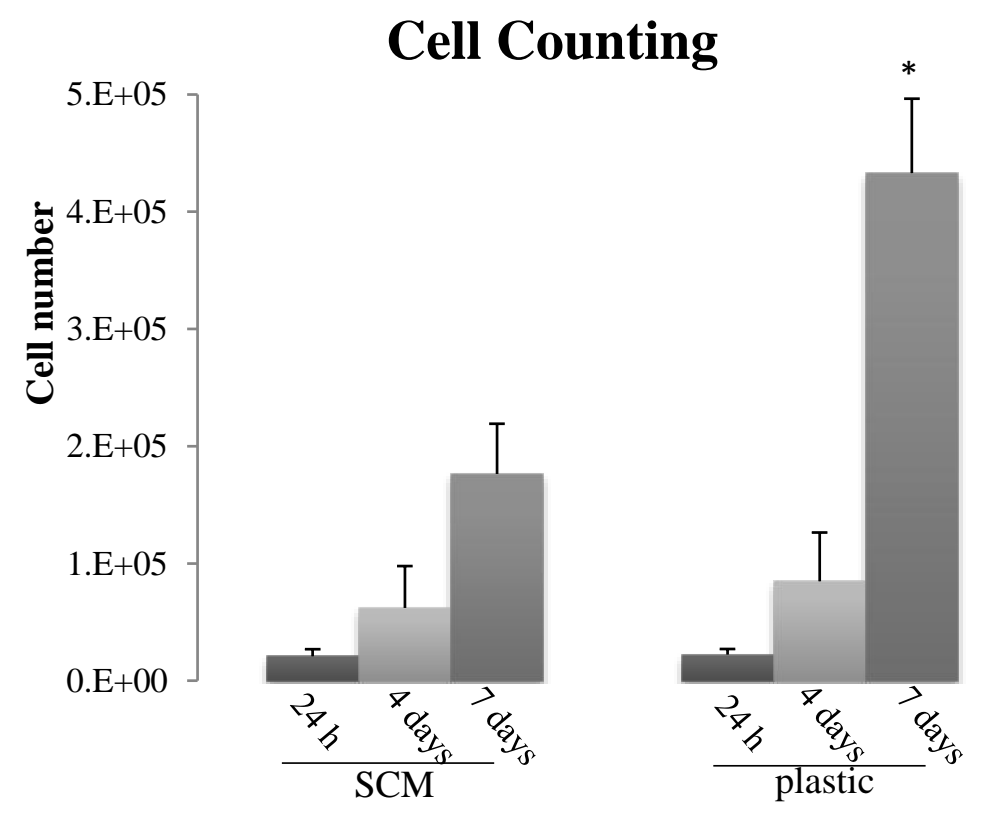

The initial decrease of MSCs proliferation on the sea urchin collagen observed in the XTT assay (Figure 6) might suggest a first "adaptation phase" encountered by the cells on the substrate (structurally very different from the flat homogeneous plastic dish); even if present (this was not observed in cell counting tests), this initial phase did not affect the following constant cell growth which led to a subsequent 3 folds increase (Figure 6). In progress studies will help to elucidate this cell behavior and to understand in detail if the SCM influences the cell cycle or the differentiation pathway. 
Figure 6. Cell proliferation assay of MSCs seeded on SCM and plastic using XTT Elisa Kit (Roche) at $24 \mathrm{~h}, 4,7,14,21$ days. Each histogram represents the mean $\pm \mathrm{SD}$ of four experiments; * $p<0.05$ plastic versus SCM.

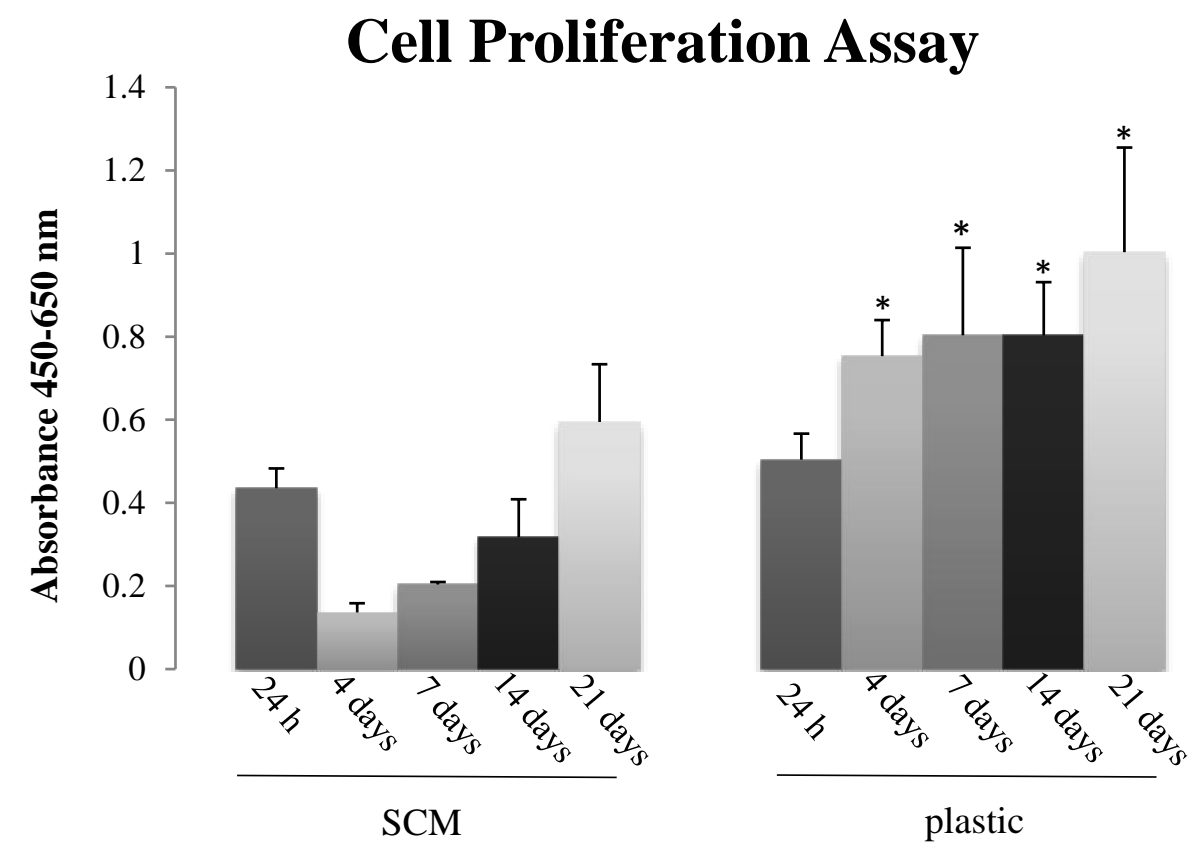

\section{Experimental Section}

Specimens of Paracentrotus lividus were collected in Paraggi (“Area Marina Protetta di Portofino") on the Ligurian coast of Italy. Once transported to the Department of Biosciences (Milan), animals were immediately dissected and their oral halves were stored at $-20{ }^{\circ} \mathrm{C}$.

\subsection{Extraction of Collagen from the PM of P. lividus}

PMs were dissected on ice from frozen oral halves, minced, left in an hypotonic buffer (10 $\mathrm{mM}$ Tris, $0.1 \%$ EDTA) for $12 \mathrm{~h}$ (RT) and rinsed with a decellularizing solution (10 mM Tris, $0.1 \%$ SDS) for $12 \mathrm{~h}$ (RT). After several and careful washings in PBS, the solution was replaced by a disaggregating solution $(0.5 \mathrm{M} \mathrm{NaCl}, 0.1 \mathrm{M}$ Tris- $\mathrm{HCl} \mathrm{pH} 8.0,0.1 \mathrm{M} \beta$-mercapto-ethanol, $0.05 \mathrm{M}$ EDTA-Na) according to Matsumura [18]. The suspension was then filtered and dialyzed against $0.5 \mathrm{M}$ EDTA-Na solution (pH 8.0) for $3 \mathrm{~h}$ (RT) and successively against distilled water overnight (RT). Long term storage of the obtained collagen suspension was performed by freezing $1.5 \mathrm{~mL}$ aliquots at $-20{ }^{\circ} \mathrm{C}$ or drying them $\left(37^{\circ} \mathrm{C}\right)$ in silicone molds. These samples were then used for production of either cell culture substrates or samples for mechanical testing (see below).

\subsection{Ultrastructural Analysis of Isolated Collagen Fibrils}

A $50 \mu \mathrm{L}$ drop of fibril suspension was placed on a 300 mesh copper grid with FORMVAR membrane. After $5 \mathrm{~min}$, the suspension in excess was removed by a filter paper. The grid was stained with uranyl acetate $2 \%(10 \mathrm{~min})$ and with lead citrate $(5 \mathrm{~min})$ and subsequently observed at the transmission electron microscope (TEM JEOL SX 100, Tokyo, Japan). 


\subsection{Cuprolinic Blue Staining for GAG Visualization in Isolated Collagen Fibrils}

The isolated collagen samples were applied to 200 mesh Formvar-coated grids. After 5 min, the suspension in excess was removed by a filter paper. The grids were stained with Cuprolinic blue by exposing them sequentially to the following solutions for the indicated times and number of washings [19]: $500 \mathrm{mM} \mathrm{NaC1}(60 \mathrm{~s} \times 1)$, fixative solution $(2.5 \%$ glutaraldehyde, $25 \mathrm{mM}$ sodium acetate, $300 \mathrm{mM} \mathrm{MgCl} 2, \mathrm{pH} 5.6 ; 60 \mathrm{~s} \times 1)$, Cuprolinic blue $(60 \mathrm{~s} \times 1)$, fixative solution $(30 \mathrm{~s} \times 2)$, sodium tungstate $(60 \mathrm{~s} \times 1)$, water $(30 \mathrm{~s} \times 2)$, $1 \%$ uranyl acetate $(60 \mathrm{~s} \times 1)$, and water $(30 \mathrm{~s} \times 2)$. Isolated and unstained fibrils were used as a control. The grids were then observed at the transmission electron microscope (TEM JEOL SX 100, Tokyo, Japan).

\subsection{SDS-PAGE Analyses of the Collagen Suspension}

A $1 \mathrm{~mL}$ of stocked collagen suspension (in distilled water) was centrifuged $(10,000 \times \mathrm{g}, 45 \mathrm{~min}$, $4{ }^{\circ} \mathrm{C}$ ), the supernatant was discharged and $1 \mathrm{~mL}$ of pepsin $(1 \mathrm{mg} / \mathrm{mL})$ in acetic acid $0.5 \mathrm{M}$ was added. Samples were left $48 \mathrm{~h}\left(4{ }^{\circ} \mathrm{C}\right)$ on an rotary shaker, centrifuged $\left(17,000 \times g, 1 \mathrm{~h}, 4{ }^{\circ} \mathrm{C}\right)$ and the supernatant was collected in another tube. $\mathrm{NaCl}$ was added to reach a final concentration of $5 \mathrm{M}$, then samples were left on the rotary shaker overnight to allow collagen precipitation $\left(4{ }^{\circ} \mathrm{C}\right)$. The day after samples were centrifuged $\left(16,000 \times g, 1 \mathrm{~h}, 4{ }^{\circ} \mathrm{C}\right)$, the supernatant was discharged and $500 \mu \mathrm{L}$ of distilled water were added. The obtained solution was mixed with sample buffer $(2: 1)$, heated at $95{ }^{\circ} \mathrm{C}$ for $5 \mathrm{~min}$, and run over a 10\% precast gel (Biorad, Hercules, CA, USA) at a constant voltage of $150 \mathrm{~V}$. $10 \mu \mathrm{L}$ of Precision Plus Protein ${ }^{\mathrm{TM}}$ Dual Color Standards (Biorad, Hercules, CA, USA) were used for molecular weight (MW) determination. The separated proteins were visualized by staining with Coomassie Blue R-250.

\subsection{Production of SCM for Cell Cultures}

The concentration of the stored collagen suspension was calculated from a sub-sample as follows: $500 \mu \mathrm{L}$ of the suspension were diluted in few millilitres of distilled water and centrifuged at $50 \times g$ (10 min) to remove possible undissociated material. The supernatant was then centrifuged at $2000 \times g$ (20 min) to obtain a pellet of collagen, and resuspended in $500 \mu \mathrm{L}$ of deionized water. The so obtained collagen suspension was dried in a silicon mold at $37{ }^{\circ} \mathrm{C}$, overnight. The resulting solid sheet of collagen was weighted and the obtained value was used to calculate the original collagen concentration. Once having this information, the remaining collagen suspension was centrifuged at $50 \times g(10 \mathrm{~min}$.) and then at $2000 \times g$ for $20 \mathrm{~min}$. The pellet was rinsed with $0.01 \%$ TritonX-100 in a proper volume to reach $2 \mathrm{mg} / \mathrm{L}$ final collagen concentration. $300 \mu \mathrm{L}$ of collagen suspension were placed in each 24-multiwells dish and left at $37{ }^{\circ} \mathrm{C}$ overnight. The so obtained SCM were then exposed to $300 \mu \mathrm{L}$ EDC/NHS cross-linker solution (EDC $30 \mathrm{mM} / \mathrm{NHS} 15 \mathrm{mM}$ in MES buffer $100 \mathrm{mM}$ ) for $4 \mathrm{~h}$ and subsequently washed several times with PBS, distilled water and ethanol 70\%. In order to check their suitability (cleanness and homogeneity), the obtained SCMs were observed under the inverted microscope Axiovert 200M (Zeiss, Oberkochen, Germany)—AxioCam HRM HAL 100, equipped with an image acquisition system Axio Vision Rel 4.5. Prior to use, SCM were carefully washed with Leibovitz medium, the same used in the following cell cultures. 


\subsection{Production of SCM for Mechanical Tests}

The protocol's first steps were the same previously described for cell culture substrates production. Then $800 \mu \mathrm{L}$ of the $2 \mathrm{mg} / \mathrm{mL}$ suspension were placed in a specifically prepared rubber silicone mold $(10 \mathrm{~mm} \times 16 \mathrm{~mm})$ and left to dry at $37{ }^{\circ} \mathrm{C}$ overnight. Samples were then treated as previously described with EDC/NHS solution and washed with PBS and distilled water. The so obtained SCM were then cut into small strips $(2 \mathrm{~mm} \times 10 \mathrm{~mm})$ to be tested for mechanical tests. Four strips were used for thickness evaluation by confocal microscopy (Leica TCSNT confocal laser microscope, Wetzlar, Germany) and/or SEM (LEO-1430, Zeiss, Oberkochen, Germany).). For confocal analysis strips were stained with Sirius red $(50 \mu \mathrm{M}$ in acetic acid $0.5 \mathrm{M})$ for $20 \mathrm{~min}$, then washed with PBS to remove the residues of the dye and mounted on a glass slide. Thickness of sample for mechanical tests was 11-12 $\mu \mathrm{m}$.

\subsection{Scanning Electron Microscopy (SEM)}

SCMs were washed in $0.1 \mathrm{M}$ sodium cacodylate buffer overnight and then fixed with $2 \%$ glutaraldehyde in $0.1 \mathrm{M}$ cacodylate buffer $\left(2 \mathrm{~h}, 4{ }^{\circ} \mathrm{C}\right)$. This fixation preceded a secondary fixation with $1 \%$ osmium tetroxyde in $0.1 \mathrm{M}$ sodium cacodylate buffer $(2 \mathrm{~h}, \mathrm{RT})$. After being washed with distilled water, samples were dehydrated with increasing percentages of ethanol $(25 \%, 50 \%, 70 \%, 90 \%, 100 \%)$. Absolute ethanol was gradually substituted with HMDS (Hexamethyldisilazane) (25\%, 50\%, 75\%, $100 \%)$. After that, SCMs were left to dry on a filter paper. Samples were then mounted on stubs and covered with pure gold (Agar SEM Auto Sputter, Stansted, UK). Finally, samples were observed at the scanning electron microscope (LEO-1430, Zeiss, Oberkochen, Germany).

\subsection{Mechanical Tests}

The mechanical properties of SCM were investigated under creep (isotonic test) and force-extension (isometric tests) conditions. The experimental apparatus consisted of an isotonic force transducer (Harvard Apparatus, Holliston, MA, USA) or an isometric force transducer (LCM System Ltd., Newport, UK) plugged to a PowerLab 2/26 recorder device (AD Instrument, Dunedin, New Zealand) via pre-amplifier. All the data originated from the mechanical tests were recorded with Labchart 7 software (AD Instrument, Dunedin, New Zealand). Each SCM strip was fixed at the two ends to rigid plastic supports with cyanoacrylate cement (Superattak ${ }^{\circledR}$, Heckel, Düsseldorf, Germany) so that the strip length left between the supports was $6 \mathrm{~mm}$. Each strip was photographed before testing (Figure 7).

In order to mimic as much as possible a physiological condition under mechanical stress all the SCMs were tested in L-15 Leibovitz cell culture medium; samples were immersed and hold in position 5 min before the test started and kept in immersion for all the duration of the experiments. 
Figure 7. LM. SCM for mechanical test. Plastic support (ps), sea urchin collagen matrix $(\mathrm{scm})$.

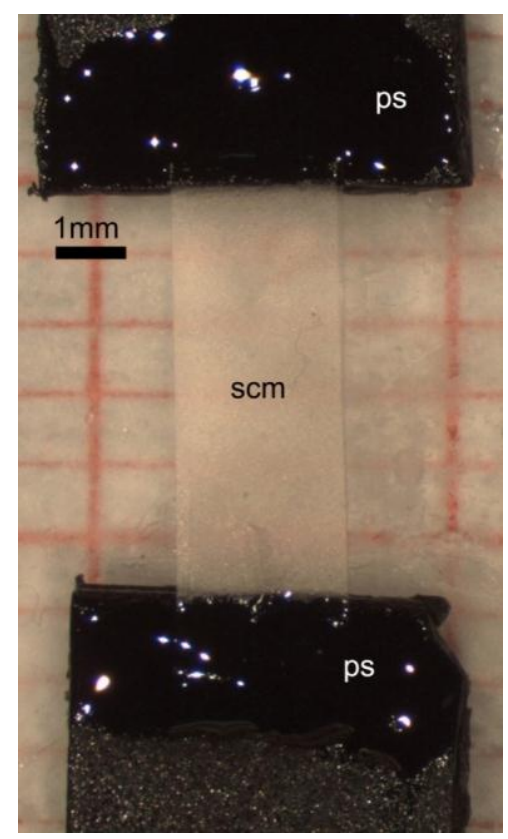

\subsubsection{Creep Tests}

Twenty-nine strips were used for creep tests. The upper part of each strip was connected with a stainless steel chain to the lever of the isometric force transducer; the lower part was tightly clamped to a fixed hook. A locking device prevented the elongation of the samples before the start of the test. From the obtained curves we extrapolated the strain rate in order to calculate the viscosities of the samples. The breaking load was the load at which the samples broke. Viscosity values were calculated as follows:

$$
\begin{gathered}
\text { Coefficient of viscosity }(\mathrm{MPa} \cdot \mathrm{s})=\frac{\text { Nominal stress }}{\text { strain rate }} \\
\text { Nominal stress }\left(\mathrm{N} / \mathrm{mm}^{2}\right)=\frac{\text { Force }}{\text { Initial CSA ( sample cross section area })} \\
\text { Strain rate }=\frac{\Delta l}{\Delta t(\mathrm{~mm} / \mathrm{s})}
\end{gathered}
$$

\subsubsection{Force-Extension Test}

Nineteen strips were used for force-extension tests. The upper part of the strip was attached to the force transducer with a stainless steel chain whereas the lower part was fixed to a hook connected with a micromanipulator. Samples were subjected to elongation of $0.1 \mathrm{~mm}$ every $10 \mathrm{~s}$ until rupture or until reaching the maximum load of the transducer. The force peaks generated at each elongation step were used to produce a stress-strain curve; the tangent to the steepest straight-line portion of each curve was used to calculate the stiffness of each sample. The breaking strain and breaking stress were obtained from the curves when samples underwent rupture. Stiffness values were calculated as follows: 


$$
\begin{gathered}
\text { Stiffness }(M P a)=\frac{\Delta \text { stress }}{\Delta \text { strain }} \\
\Delta \text { Stress }(M P a)=\frac{\Delta F}{C S A} \\
\Delta \text { strain }=\frac{\Delta l}{l(\text { starting sample length })}
\end{gathered}
$$

\subsection{Biocompatibility}

\subsubsection{Mesenchymal Stromal Cell Cultures}

Mesenchymal stromal cells (MSCs) were obtained from equine peripheral blood by gradient separation [70] and they were maintained at $37{ }^{\circ} \mathrm{C}$ in an incubator with an atmosphere of humidified air $5 \% \mathrm{CO}_{2}$ in growth medium.

\subsubsection{Cell Counting}

The MSCs were seeded at a concentration of $2 \times 10^{4} /$ well in 6-wells (plastic wells and wells treated with MCT $5 \mathrm{mg} / \mathrm{mL}$ ) for $24 \mathrm{~h}, 4$ and 7 days. At different time points the cells were trypsinized and counted with Burker chamber. Four experiments were carried out and for each experiment 6 replicates were performed.

\subsubsection{Proliferation Assay}

Cell proliferation was evaluated using the Cell Proliferation Kit II (XTT)-base (Roche, Milan, Italy) colorimetric assay. Cells $\left(1 \times 10^{4}\right)$ were grown in 96-well tissue culture plates for $24 \mathrm{~h}, 4,7,14$ and 21 days. MSC were grown in plastic wells and in wells plated with SCM. At each time point, cells in selected wells were incubated with the yellow XTT solution for $1 \mathrm{~h}$. After incubation with XTT, the metabolically active cells developed an orange formazan product, which was quantified using an enzyme-linked immunosorbent assay plate reader (Spectra Count, Perkin Elmer, Milan, Italy). The amount of orange formazan produced was directly correlated to the number of living cells. Four experiments were carried out and for each experiment three replicates were performed.

\subsection{Statistical Analysis}

Data are expressed as the mean \pm SD. Statistical analysis was performed using the paired Student $t$-test (SPSS software, version 11.0). The level of statistical significance was set at $p \leq 0.05$.

\section{Conclusions}

The sea urchin is a well known and common experimental model widely used in basic and applied biology. P. lividus is also an edible species, appreciated for the delicacy of its gonads and therefore collected and often cultured in many countries for alimentary purposes. All the non-edible 
body parts, such as the PM, could be collected and used as a recycled material for producing low-cost collagen substrates.

The protocol here proposed and developed allows us to obtain native collagen fibrils in sufficient amount and purity to produce a cohesive matrix. High resistance to mechanical stress and elasticity are the main viscoelastic properties of the produced SCM, which therefore might be suitably employed for specific tissue engineering applications such as tendon or skin regeneration (Tables 1-3). Alternatively, they might be useful as highly resistant dermal stitches for surgical purpose or skin tape for topical applications (lacerations or burns). Furthermore, our results showed that the sea urchin collagen matrices may be successfully seeded with mesenchymal stromal cells isolated from equine blood thus indicating they can be a promising clinical tool for mammalian damaged tissues in regenerative medicine. Further ongoing in vitro and in vivo tests will help to confirm the SCM biocompatibility. In conclusion, we think that the SCM might provide cells a more biomimetic environment in terms of structure (fibrillar), biochemical composition (collagen) and mechanical characteristics than other existing substrates.

\section{Acknowledgments}

This research was funded by CARIPLO Foundation (MIMESIS Project-Advanced Materials 2009). We would like to deeply thank I. Wilkie, for his fundamental help in mechanical testing, and the CIMA center (Centro Interdipartimentale Microscopia Avanzata) for technical support in microscopy imaging. We are grateful to the "Area Marina Protetta of Portofino" for permission to collect experimental animals.

\section{Author Contributions}

Conceived and designed the experiments: C. Di Benedetto, A. Barbaglio, T. Martinello, D. Fassini, E. Cullorà, M.A. Barbosa, M. Sugni. Performed the experiments: C. Di Benedetto, T. Martinello, V. Alongi. Analyzed the data: C. Di Benedetto, A. Barbaglio, T. Martinello, D. Fassini, F. Bonasoro, M. Sugni. Contributed reagents/materials/analysis tools: M. Patruno, M.D. Candia Carnevali, M. Sugni. Wrote the paper: C. Di Benedetto, A. Barbaglio, T. Martinello, D. Fassini, F. Bonasoro, M.D. Candia Carnevali, M. Sugni.

\section{Conflicts of Interest}

The authors declare no conflict of interest.

\section{References}

1. Barnes, C.P.; Pemble, C.W.; Brand, D.D.; Simpson, D.G.; Bowlin, G.L. Cross-linking electrospun type II collagen tissue engineering scaffolds with carbodiimide in ethanol. Tissue Eng. 2007, 13, 1593-1605.

2. Stamov, D.R.; Pompe, T. Structure and function of ecm-inspired composite collagen type I scaffolds. Soft Matter 2012, 8, 10200-10212. 
3. Song, E.; Kim, S.Y.; Chun, T.; Byun, H.J.; Lee, Y.M. Collagen scaffolds derived from a marine source and their biocompatibility. Biomaterials 2006, 27, 2951-2961.

4. Arias-Moscoso, J.L.; Soto-Valdez, H.; Plascencia-Jatomea, M.; Vidal-Quintanar, R.L.; Rouzaud-Sández, O.; Ezquerra-Brauer, J.M. Composites of chitosan with acid-soluble collagen from jumbo squid (Dosidicus gigas) by-products. Polym. Int. 2011, 60, 924-931.

5. Green, D.; Howard, D.; Yang, X.; Kelly, M.; Oreffo, R.O. Natural marine sponge fiber skeleton: A biomimetic scaffold for human osteoprogenitor cell attachment, growth, and differentiation. Tissue Eng. 2003, 9, 1159-1166.

6. Ehrlich, H. Chitin and Collagen as Universal and Alternative Templates in Biomineralization. Int. Geol. Rev. 2010, 52, 661-699.

7. Ehrlich, H.; Deutzmann, R.; Capellini, E.; Koon, H.; Solazzo, C.; Yang, Y.; Ashford, D.; Thomas-Oates, J.; Lubeck, M.; Baessmann, C.; et al. Mineralization of the Meter-long Biosilica Structures of Glass Sponges is template on Hydroxylated Collagen. Nat. Chem. 2010, 2, 1084-1088.

8. Giraud-Guille, M.M.; Besseau, L.; Chopin, C.; Durand, P.; Herbage, D. Structural aspects of fish skin collagen which forms ordered arrays via liquid crystalline states. Biomaterials 2000, 21, 899-906.

9. Nagai, T.; Yamashita, E.; Taniguchi, K.; Kanamori, N.; Suzuki, N. Isolation and characterisation of collagen from the outer skin waste material of cuttlefish (Sepia lycidas). Food Chem. 2001, 72, $425-429$.

10. Wilkie, I.C.; Carnevali, M.D.C.; Andrietti, F. Microarchitecture and mechanics of the sea-urchin peristomial membrane. Ital. J. Zool. 1994, 61, 39-51.

11. Bonasoro, F.; Carnevali, M.D.C.; Wilkie, I.C. The peristomial membrane of regular sea-urchinsFunctional-morphology of the epidermis and coelomic lining in Paracentrotus lividus (Lamarck). Ital. J. Zool. 1995, 62, 121-135.

12. Wilkie, I.C. Mutable collagenous tissue: overview and biotechnological perspective. Prog. Mol. Subcell. Biol. 2005, 39, 221-250.

13. Barbaglio, A. Department of Biosciences, University of Milan, Italy. The PM collagen is similar to the mammalian type-I, 2014. (personal communication)

14. Ribeiro, A.R.; Barbaglio, A.; Benedetto, C.D.; Ribeiro, C.C.; Wilkie, I.C.; Carnevali, M.D.C.; Barbosa, M.A. New insights into mutable collagenous tissue: Correlations between the microstructure and mechanical state of a sea-urchin ligament. PLos One 2011, 6, e24822.

15. Boudouresque, C.F.; Verlaque, M. Paracentrotus lividus. Dev. Aquac. Fish Sci. 2013, 38, 297-327.

16. Engler, A.J.; Griffin, M.A.; Sen, S.; Bonnemann, C.G.; Sweeney, H.L.; Discher, D.E. Myotubes differentiate optimally on substrates with tissue-like stiffness: Pathological implications for soft or stiff microenvironments. J. Cell Biol. 2004, 166, 877-887.

17. Murphy, C.M.; Matsiko, A.; Haugh, M.G.; Gleeson, J.P.; O’Brien, F.J. Mesenchymal stem cell fate is regulated by the composition and mechanical properties of collagen-glycosaminoglycan scaffolds. J. Mech. Behav. Biomed. 2012, 11, 53-62.

18. Matsumura, T. Collagen fibrils of the sea cucumber, Stichopus japonicus: Purification and morphological study. Connect. Tissue Res. 1974, 2, 117-125.

19. Trotter, J.A.; Koob, T.J. Collagen and proteoglycan in a sea urchin ligament with mutable mechanical properties. Cell Tissue Res. 1989, 258, 527-539. 
20. Barbaglio, A.; Tricarico, S.; Ribeiro, A.; Ribeiro, C.; Sugni, M.; Di Benedetto, C.; Wilkie, I.; Barbosa, M.; Bonasoro, F.; Candia Carnevali, M.D. The mechanically adaptive connective tissue of echinoderms: Its potential for bio-innovation in applied technology and ecology. Mar. Environ. Res. 2012, 76, 108-113.

21. Elliott, J.T.; Tona, A.; Woodward, J.T.; Jones, P.L.; Plant, A.L. Thin films of collagen affect smooth muscle cell morphology. Langmuir 2003, 19, 1506-1514.

22. Chung, K.H.; Bhadriraju, K.; Spurlin, T.A.; Cook, R.F.; Plant, A.L. Nanomechanical properties of thin films of type I collagen fibrils. Langmuir 2010, 26, 3629-3636.

23. Steven, F.S.; Jackson, D.S.; Schofield, J.D.; Bard, J.B. Polymeric collagen isolated from the human intestinal submucosa. Gut 1969, 10, 484-487.

24. Tajima, S.; Nagai, Y. Isolation and partial characterization of collagen fibrils, fibers and fiber-bundles from insoluble calf dermis. Connect. Tissue Res. 1980, 7, 157-163.

25. Craig, A.S.; Birtles, M.J.; Conway, J.F.; Parry, D.A.D. An estimate of the mean length of collagen fibrils in rat tail-tendon as a function of age. Connect. Tissue Res. 1989, 19, 51-62.

26. Birk, D.E.; Hahn, R.A.; Linsenmayer, C.Y.; Zycband, E.I. Characterization of collagen fibril segments from chicken embryo cornea, dermis and tendon. Matrix Biol. 1996, 15, 111-118.

27. Friess, W.; Lee, G. Basic thermoanalytical studies of insoluble collagen matrices. Biomaterials 1996, 17, 2289-2294.

28. De Vente, J.E.; Lester, G.E.; Trotter, J.A.; Dahners, L.E. Isolation of intact collagen fibrils from healing ligament. J. Electron Microscopy 1997, 46, 353-356.

29. White, J.F.; Werkmeister, J.A.; Darby, I.A.; Bisucci, T.; Birk, D.E.; Ramshaw, J.A.M. Collagen fibril formation in a wound healing model. J. Struct. Biol. 2002, 137, $23-30$.

30. Crabb, R.A.B.; Chau, E.P.; Evans, M.C.; Barocas, V.H.; Hubel, A. Biomechanical and microstructural characteristics of a collagen film-based corneal stroma equivalent. Tissue Eng. 2006, 12, 1565-1575.

31. Bozec, L.; van der Heijden, G.; Horton, M. Collagen fibrils: Nanoscale ropes. Biophys. J. 2007, 92, 70-75.

32. Amyot, F.; Small, A.; Boukari, H.; Sackett, D.; Elliott, J.; McDaniel, D.; Plant, A.; Gandjbakhche, A. Thin films of oriented collagen fibrils for cell motility studies. J. Biomed. Mater. Res. Part B Appl. Biomater. 2008, 86, 438-443.

33. Thurmond, F.A.; Trotter, J.A. Morphology and biomechanics of the microfibrillar network of sea cucumber dermis. J. Exp. Biol. 1996, 199, 1817-1828.

34. Omura, Y.; Urano, N.; Kimura, S. Occurrence of fibrillar collagen with structure of $\left(\alpha_{1}\right)_{2} \alpha_{2}$ in the test of sea urchin Asthenosoma ijimai. Comp. Biochem. Phys. B 1996, 115, 63-68.

35. Cluzel, C.; Lethias, C.; Garrone, R.; Exposito, J.Y. Distinct maturations of $n$-propeptide domains in fibrillar procollagen molecules involved in the formation of heterotypic fibrils in adult sea urchin collagenous tissues. J. Biol. Chem. 2004, 279, 9811-9817.

36. Heim, A.J.; Matthews, W.G.; Koob, T.J. Determination of the elastic modulus of native collagen fibrils via radial indentation. Appl. Phys. Lett. 2006, 89, 181902.

37. Heinemann, S.; Ehrlich, H.; Douglas, T.; Heinemann, C.; Worch, H.; Schatton, W.; Hanke, T. Ultrastructural studies on the collagen of the marine sponge Chondrosia reniformis Nardo. Biomacromolecules 2007, 8, 3452-3457. 
38. Damink, L.H.H.O.; Dijkstra, P.J.; vanLuyn, M.J.A.; vanWachem, P.B.; Nieuwenhuis, P.; Feijen, J. Cross-linking of dermal sheep collagen using a water-soluble carbodiimide. Biomaterials 1996, 17, 765-773.

39. Scotchford, C.A.; Cascone, M.G.; Downes, S.; Giusti, P. Osteoblast responses to collagen-pva bioartificial polymers in vitro: The effects of cross-linking method and collagen content. Biomaterials 1998, 19, 1-11.

40. Yang, C.R. Enhanced physicochemical properties of collagen by using EDC/NHS-crosslinking. Bull. Mater. Sci. 2012, 35, 913-918.

41. Angele, P.; Abke, J.; Kujat, R.; Faltermeier, H.; Schumann, D.; Nerlich, M.; Kinner, B.; Englert, C.; Ruszczak, Z.; Mehrl, R.; et al. Influence of different collagen species on physico-chemical properties of crosslinked collagen matrices. Biomaterials 2004, 25, 2831-2841.

42. Tanaka, Y.; Yamaoka, H.; Nishizawa, S.; Nagata, S.; Ogasawara, T.; Asawa, Y.; Fujihara, Y.; Takato, T.; Hoshi, K. The optimization of porous polymeric scaffolds for chondrocyte/ atelocollagen based tissue-engineered cartilage. Biomaterials 2010, 31, 4506-4516.

43. Krishnamoorthy, G.; Selvakumar, R.; Sastry, T.P.; Mandal, A.B.; Doble, M. Effect of D-amino acids on collagen fibrillar assembly and stability: Experimental and modelling studies. Biochem. Eng. J. 2013, 75, 92-100.

44. Di Benedetto, C. Progenitor Cells and Regenerative Potential in Echinoderms: An in Vivo and in Vitro Approach; Lambert Academic Publishing: Saarbrucken, Germany, 2011.

45. Tricarico, S.; Barbaglio, A.; Burlini, N.; Del Giacco, L.; Ghilardi, A.; Sugni, M.; di Benedetto, C.; Bonasoro, F.; Wilkie, I.; Candia Carnevali, M.D. New insights into the mutable collagenous tissue of Paracentrotus lividus: Preliminary results. Zoosymposia 2012, 7, 7.

46. Haugh, M.G.; Murphy, C.M.; McKiernan, R.C.; Altenbuchner, C.; O’Brien, F.J. Crosslinking and mechanical properties significantly influence cell attachment, proliferation, and migration within collagen glycosaminoglycan scaffolds. Tissue Eng. Part A 2011, 17, 1201-1208.

47. Tomita, M.; Kinoshita, T.; Izumi, S.; Tomino, S.; Yoshizato, K.; Characterizations of sea urchin fibrillar collagen and its cDNA clone. Biochim. Biophys. Acta 1994, 1217, 131-140.

48. Gelse, K.; Poschl, E.; Aigner, T. Collagens-Structure, function, and biosynthesis. Adv. drug Deliv. Rev. 2003, 55, 1531-1546.

49. Mayne, J.; Robinson, J.J. Comparative analysis of the structure and thermal stability of sea urchin peristome and rat tail tendon collagen. J. Cell. Biochem. 2002, 84, 567-574.

50. Wilkie, I.C. School of Biological and Biomedical Sciences, Glasgow Caledonian University, Glasgow, Scotland. The viscosity of the sea urchin compass depressor ligament (P. Lividus) is $560.6 \pm 364.7(\mathrm{MPa} \cdot \mathrm{s})$. The stiffness of the sea urchin compass depressor ligament (P. Lividus) is $16.65 \pm 8.93$ (Mpa), 2014. (personal communication)

51. Motokawa, T. Mechanical properties and structure of the spine-joint central ligament of the sea urchin, Diadema setosum (echinodermata, echinoidea). J. Zool. 1983, 201, 223-235.

52. Motokawa, T. Connective tissue catch in echinoderms. Biol. Rev. 1984, 59, 255-270.

53. Eylers, J.P. Ion-dependent viscosity of holothurian body wall and its implications for the functional morphology of echinoderms. J. Exp. Biol. 1982, 99, 1-8. 
54. Wilkie, I. Design for disaster: The ophiuroid intervertebral ligament as a typical mutable collagenous structure. In Echinoderm Biology; Burke, R.D., Mladenov, P.V., Lambert, P., Parsley, R.L., Eds.; A.A. Balkema: Rotterdam, The Netherlands, 1988; pp. 25-38.

55. Baumiller, T.K.; Labarbera, M. Mechanical properties of the stalk and cirri of the sea lily Cenocrinus asterius. Comparative Biochem. Physiol. Part A Physiol. 1993, 106, 91-95.

56. Pioletti, D.P.; Rakotomanana, L.R.; Benvenuti, J.F.; Leyvraz, P.F. Viscoelastic constitutive law in large deformations: Application to human knee ligaments and tendons. J. Biomech. 1998, 31, $753-757$.

57. Ho, H.O.; Lin, C.W.; Sheu, M.T. Diffusion characteristics of collagen film. J. Control. Release Off. J. Control. Release Soc. 2001, 77, 97-105.

58. Hidaka, M. Effects of certain physico-chemical agents on the mechanical properties of the catch apparatus of the sea-urchin spine. J. Exp. Biol. 1983, 103, 15.

59. Motokawa, T.; Tsuchi, A. Dynamic mechanical properties of body-wall dermis in various mechanical states and their implications for the behavior of sea cucumbers. Biol. Bull. 2003, 205, 261-275.

60. van der Rijt, J.A.; van der Werf, K.O.; Bennink, M.L.; Dijkstra, P.J.; Feijen, J. Micromechanical testing of individual collagen fibrils. Macromol. Biosci. 2006, 6, 697-702.

61. Levental, I.; Georges, P.C.; Janmey, P.A. Soft biological materials and their impact on cell function. Soft Matter 2007, 3, 299-306.

62. Kerdok, A.E.; Ottensmeyer, M.P.; Howe, R.D. Effects of perfusion on the viscoelastic characteristics of liver. J. Biomech. 2006, 39, 2221-2231.

63. Gallagher, A.J.; Ní Annaidh, A.; Bruyere, K.; Otténio, M.; Xie, H.; Gilchrist, M.D. Dynamic tensile properties of human skin. In Proceedings of Ircobi Conference, Dublin, Ireland, 12-14 September 2012; International Research Council on the Biomechanics of Injury: Dublin, Ireland, 2012; pp. 494-502.

64. Duan, X.; Sheardown, H. Dendrimer crosslinked collagen as a corneal tissue engineering scaffold: Mechanical properties and corneal epithelial cell interactions. Biomaterials 2006, 27, 4608-4617.

65. Brandl, F.; Sommer, F.; Goepferich, A. Rational design of hydrogels for tissue engineering: Impact of physical factors on cell behavior. Biomaterials 2007, 28, 134-146.

66. Ryan, S.D.; Williams, J.L. Tensile testing of rodlike trabeculae excised from bovine femoral bone. J. Biomech. 1989, 22, 351-355.

67. Grover, C.N.; Gwynne, J.H.; Pugh, N.; Hamaia, S.; Farndale, R.W.; Best, S.M.; Cameron, R.E. Crosslinking and composition influence the surface properties, mechanical stiffness and cell reactivity of collagen-based films. Acta Biomater. 2012, 8, 3080-3090.

68. Lopez-Garcia, M.D.; Beebe, D.J.; Crone, W.C. Mechanical interactions of mouse mammary gland cells with collagen in a three-dimensional construct. Ann. Biomed. Eng. 2010, 38, 2485-2498.

69. Niu, G.; Criswell, T.; Sapoznik, E.; Lee, S.; Soker, S. The influence of cross-linking methods on the mechanical and biocompatible properties of vascular scaffold. J. Sci. Appl. Biomed. 2013, 1, $1-7$. 
70. Martinello, T.; Bronzini, I.; Maccatrozzo, L.; Iacopetti, I.; Sampaolesi, M.; Mascarello, F.; Patruno, M. Cryopreservation does not affect the stem characteristics of multipotent cells isolated from equine peripheral blood. Tissue Eng. Part C Methods 2010, 16, 771-781.

(C) 2014 by the authors; licensee MDPI, Basel, Switzerland. This article is an open access article distributed under the terms and conditions of the Creative Commons Attribution license (http://creativecommons.org/licenses/by/3.0/). 